\title{
EDITORIAL
}

\section{Family Planning Problem in Indonesia}

\author{
Eka R Gunardi
}

According to the world population data sheet in 2015, Indonesia was the $4^{\text {th }}$ largest population country in the world with 256 million people. ${ }^{1}$ By total fertility rate 2.6, there will be 310 millions of Indonesian people in 2035. Large population represents serious threat, as over-population is the root of environmental problems, such as unsanitary living conditions, the depletion of resources, environmental pollution, and also poverty.

One of the prerequisites for improving Indonesian people's quality of life is through balancing the population growth by controlling the quantity of population. One of the ways is through family planning. Stated at Act No. 52 of 2009 on population and family development, the family construction is the foundation to create the quality family who lives in a healthy environment. ${ }^{2}$ This law supports family planning program as a part of efforts to control the pregnancy by using contraceptives.

There are some problems in family planning program. Firstly, the contraceptive prevalence rate did not increase significantly from $60.3 \%$ in 2002 to $61.4 \%$ in 2007 . It remained constant to $61.9 \%$ in 2012 . Secondly, the total fertility rate (TFR) in same period is only slightly decreased from 3.0 to 2.6. Among ASEAN countries, Indonesia ranked the number six for the lowest fertility rates. Therefore, we still need more effort to earn better result in family planning program. ${ }^{3}$

The reason behind this phenomenon is the use of Non-LTCM (Long-Term Contraception Method) higher than LTCM. Non-LTCM, which has a duration of 1-3 months, shows higher dropout rate (25-41\%). Long Term Contraceptive Method ranging from 3 to 5 years of use provides higher chance for survival; however, the number of users are lower than Non-LTCM. This may be caused because the use of this method requires more complex action and skills of health professionals. ${ }^{4}$

Long-term contraception method (LTCM), such as IUD and Implant can be used for the spouse of fertile age that planned to delay the pregnancy; meanwhile, sterilization is used for spouse who planned to stop the fertility. ${ }^{5}$

Implant is a contraceptive containing Levonorgestrel wrapped in capsules silastic silicone (polidemtsilixane) and implanted under the skin. Implant has long service life, release stable low dose hormone, and has reversible effect for the women fertility. The successful rate of this implant contraceptive is high, nearly $100 \%{ }^{5}$

There are some types of implant contraception that available in Indonesia, those are Norplant that has six small silicone rods, Jadelle or Indoplant that has two rods. However, study about effectiveness between those types of implant in Indonesia is still not available. Therefore, in this edition, we try to compare the effectiveness of 2 and 6 rods of implant as contraceptive methods.

\section{References}

1. World Population Data Sheet. Jakarta: Population Reference Bureau, 2015.

2. Kementerian Hukum dan Hak Asasi Manusia Republik Indonesia. Undang-undang Republik Indonesia No. 52 tahun 2009 tentang perkembangan kependudukan dan pembangunan keluarga, 2009.

3. Jones G. The 2010 - 2035 Indonesian Population Projection Understanding the Causes, Consequences and Policy Options for Population and Development. United Nations Population Funds, 2016.

4. Badan Kependudukan dan Keluarga Berencana Nasional. Survey Demografi dan Kesehatan Indonesia 2012 , August 2013.

5. Saifuddin AB, Affandi B. Kontrasepsi. In: Wiknjosastro H, Saifuddin AB, Rachimhadhi T. Ilmu Kebidanan $3^{\text {rd }}$ ed. Jakarta: Yayasan Bina Pustaka Sarwono Prawirohardjo; 2007: 905-33. 